\title{
BRIEF OVERVIEW OF CLIMATE RESPONSIVE FACADES \& ITS KINETIC APPLICATIONS
}

\author{
Ahmed Abdelwahed Mekhamar 1, Ahmed Halim Hussein 2, \\ 1 Assistant lecturer, 2 Lecturer \\ Architecture Dep., Faculty of Engineering-Mattaria, Helwan University
}

\begin{abstract}
Facade systems have recently been transformed from simple passive elements to more advanced and complex active systems that are able to act in an adaptive manner and in response to the surrounding environment through changing buildings facades behaviour, in terms of spatial configurations or characteristics of its external skin. Responsive facades can improve building's energy efficiency through improving buildings energy savings by their capability to change their behaviour and/or characteristics through exploiting stimulus-responsive materials and intelligent control systems that can make a significant and valuable contribution to the success of the buildings system as a whole.

This paper intends to display a brief overview of the existing different climate responsive facades strategies through displaying a number of different environmental responsive facades behaviours as well as goals that can be achieved by the applications of such responsive facades. Based on the analysis of the illustrated case studies considered in this paper, responsive behaviour of kinetic facades is categorized under two main categories in response to two main types of stimuli that usually buildings are subjected to which are solar radiation and natural air current. Each one of these types is categorized into other sub categories which vary according to a number of different factors such as the design strategy, desired function or applied technology. the applications of kinetic solar responsive facades in this research is divided into three main types, which are responding through architectonic building movement, transformable shading systems and integrated kinetic shading systems with PV cells. While natural air current and wind driven kinetic responsive facades are divided in to two main types, which are air current responsive facades and integrated air current responsive facades with wind energy collectors.
\end{abstract}

Adaptive architecture generally and responsive facades strategies specifically with its wide range of applications is considered as an emergent and significant research topic, based on its capability of reducing buildings energy consumption rates drastically as well as improving the indoor living environments. 
Keywords: Responsive façades, Kinetic facades, Kinetic shading, Solar energy, Wind energy, Solar responsive facades, Airflow responsive facades.

\section{1- Introduction:}

In the last decades, responsive facades applications have been extensively approached due to the significant role it plays in conserving energy and raising comfort levels, that's why many researches have been carried out recently about different responsive facade strategies and applications.

Building facades are subjected to a wide range of changing external climate conditions due to their location at the boundary between inside and outside, conventional building facades typically have static properties, with no ability to respond to these changes, therefore making the shift to climate responsive building facades may offer opportunities through taking advantage of the adaptive capabilities and therefore allows for the transformation from 'manufactured indoor environments' to 'naturally lit \& ventilated indoor environments' [1]. This paper is mainly concerned about the behaviour of kinetic buildings facades and its responsiveness to external climate conditions, through the ability to repeatedly and reversibly change some of its characteristics, features or behaviour over time in order to respond to changing occupant's requirements and variable climate conditions, with the aim of improving the overall building performance and indoor environmental quality.

\section{Climate Adaptive Façades as a Mediator:}

The recent development that occurred in building design practices have led to the creation of a countless number of buildings with facades similar to each other, regarding the used materials, appearance and design approach, creating uncomfortable indoor environments that are totally isolated from external environments and totally dependent on both electrical and mechanical systems during large periods of time to meet the user's needs. This dependency on both electrical and mechanical systems, has increased buildings energy consumption rates through the applications of mechanical ventilation, air heating/cooling systems, lighting systems and all the other systems needed to provide an acceptable and comfortable indoor environmental quality, that require not only energy input but also requires advanced control systems in order to be able to follow the continuously changing ambient conditions. Such continuous demand leads to the creation of manufactured indoor spaces covered with buildings facades which acts in most of cases as a barrier that aims to block any interaction between the buildings indoor and the surrounding ambient, instead of acting as a mediator between the inside of the building and the external environmental conditions.

From the above, we can understand that although building envelopes primary function is to conserve energy and control occupants comfort, with additional attention during the preliminary design process, climate adaptive facades can have the ability to maximize occupant's comfort, through thermal control, air quality \& ventilation, daylight and humidity, while also minimizing buildings running costs and energy consumption rates to the minimum through reducing the usage of electricity and even in some situations to transform electrical energy from the different renewable natural sources rather than only decreasing buildings energy consumption rates and electrical demand. 


\section{Climate Kinetic Responsive Façade Types:}

Normally, climate responsive façades act in response to external ambient factors in the purpose of providing acceptable indoor environmental conditions which can be described in terms of thermal comfort, indoor air quality, acoustic performance and visual performance, as the way building façades respond to external factors can have huge influence on the human comfort and satisfaction in multiple ways.

Climate responsive façade can have many different classifications according to its control types, used materials, movement strategies, applied technologies, etc. while in this research kinetic responsive facades are categorized based on the affecting stimuli which is in this case, the climatic factor it is responding to, at which its behavior is based on an occurrence of change in heat, light, or air current. This research is mostly concerned about exploring and clarifying the two most significant environmental responsive façade types, which are solar responsive facades and natural air current (wind driven) responsive facades. (fig,1)

The first type is the solar responsive facades which continuously adapts to external solar radiation in the form of the amount of daylight that needs to be balanced continuously during the day in order to provide both thermal and visual comfortable indoor conditions, as well as the thermal gain from solar radiations which continuously change throughout the day and throughout the year and is one of the most affecting factors on passive heating and cooling design. The second type is wind and air current responsive facades, as air current and wind are considered to be a significant environmental factor that is needed to be taken into consideration in buildings design as it can significantly affect occupants comfort as well as building performance [2].

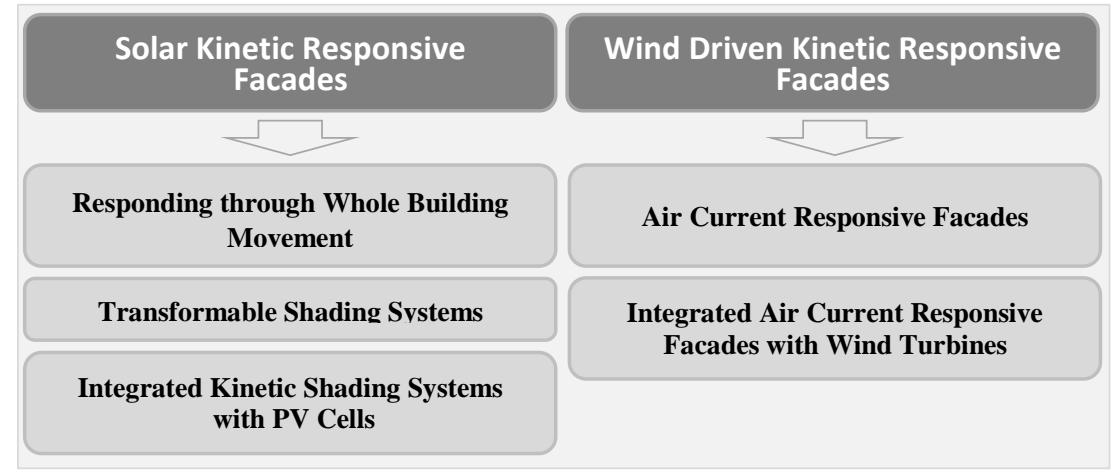

\subsection{Solar Kinetic Responsive Facades:}

Solar responsive facades are responsive to the variable amount of solar radiation that buildings are subjected to most of the times in different formats, and can usually be achieved through the control of solar heat, solar light or both. In order to achieve this, different strategies can be implemented in the dynamic façade design such as, kinetic movement whether of the whole building or only parts of it or through the common applications of external kinetic shading strategies.

Another significant purpose of solar kinetic responsive facades applications can sometimes be generating electrical energy from solar energy in order to decrease buildings demands and to improve buildings overall performance through the complete or partial dependence on energy harvested from natural and renewable resources. 


\section{- Responding through Whole Building Movement:}

This type of movement is considered to be complicated as sometimes the design requires the whole building or some parts of it to move or rotate. An example of the whole building kinetic movement is Heliotrope solar house in Germany, (Fig.1a) which is the world's first energy positive solar house, the building is mounted on a pole, and it is set to rotate around 180 degrees through the day, in response to the preferred solar orientation. Despite the fact that the fixed solar panels installed on the top of the building produce the energy needed to make it a positive solar house, we are mostly interested about the kinetic motion strategy of the whole structure of the building that rotates so as to direct windows towards the sun in winter while during summer the building rotates to provide shade [3]. A different type of motion can be found in the Sharifi-ha House in Iran (Fig.2b), at which the building facade is composed of three movable boxes with a new and innovative structural system [4], this system allows the three parts of the house to individually and dynamically respond to solar radiation and occupants needs, through sliding \& rotating to provide different angles of solar exposure throughout the day.

One of the most recent and significant examples clarifying the innovation in creating buildings that moves is the Quadrant House in Poland (Fig.1c). The idea behind the design was to provide part of the house with the ability to move and to react according to the movement of the sun during the day and the year. The terrace of the house is designed to rotate independently with different angles, and the control system is fully automated in direct response to the sun and solar radiation, in order to provide higher levels of shade in summer and to allow more sunlight penetration during winter [5].

\section{- Transformable Shading Systems:}

This type can be demonstrated through either traditional manually operated shading systems or modern mechanical systems that has a wide range of innovative applications and movements, such as (rotational, retractable, sliding, active daylighting and self-adjusting kinetic applications). One of the first architects who applied the concept of kinetic shading in buildings facades design in a magnificent and innovative way was Jean Nouvel, who created a modern mashrabia-like screen placed on the south facade of the iconic building Institut du Monde Arabe (Fig.2a). Being inspired by the architecture of the middle east, the architect created a novel sun screen composed of a huge number of responsive metallic brise soleil units that are automatically controlled so as to modulate daylight penetration and solar heat gain throughout the day [6].

A more common application of kinetic responsive solar radiation shading systems can be found in Melbourne's Council House 2 building (Fig.2b) constructed in 2006. At which the west façade of the building is completely covered by a large number of vertical kinetic timber louvers that are controlled by photocells which tracks the sun's path and changes the louvers rotation angle accordingly [7] in order to provide the most appropriate indoor day lighting levels and thermal conditions. One year later in Austria, Kiefer Technic Showroom building (Fig.2c) was constructed, which is considered to be another significant building with an innovative folding responsive façade. The external façade is composed of aluminium panels that can be both automatically and individually controlled so as to open and close through vertically folding and has the ability to change its form continuously throughout the day in order 
to reach the most desired indoor lighting and thermal conditions [8].

Another vertical kinetic shading system was applied on the external facades of the Q1 building, ThyssenKrupp's Headquarters (Fig.2d), while this time, the innovative sun shading facade is composed of stainless steel lamellas made of horizontal cantilevered slats, which are all connected to a central stud that have the ability to twist independently, and rotate through a certain range of angles (from $0^{\circ}$ to $90^{\circ}$ ), for the sake of enabling daylight control without blocking the view [9]. While in Kuggen building, a rotational kinetic shading strategy is applied through the installation of a solar tracking movable sun screen that is installed to rotate around the top floors of the circular building [10]. the rotating sun screened was designed to be a photovoltaic shade screen, and its motion is responsive to the sun ray's movement around the building throughout the day (Fig.2e).

One last example of applying kinetic shading strategies in building facades is the iconic building Al Bahar Towers in Dubai (Fig.2f). At which the building's responsive façade is a remarkable example of origami shading, the building façade is composed of a unique shading screen composed of a group of origami shaped triangles, placed two meters outside the buildings' exterior on an independent frame [11]. Each one of the triangles is coated with fiberglass and is folded in a multi axis direction and programmed to move in response to the movement of the sun.

\section{- Integrated Kinetic Shading Systems with PV Cells:}

Installing kinetic shading features on external buildings facades helps in improving indoor quality through decreasing thermal load gains \& regulating daylight penetration during the day as well as improving building's overall performance. while installing kinetic features with solar energy collection has more goals further than the improvement of indoor quality and building performance, as it seeks to efficiently decrease buildings energy consumption through generating electricity from renewable sources (solar radiation), and in some cases the system can be connected to the main utility grid in order to sell energy if the collected energy is more than the buildings own consumption. This type of shading usually relies on installing integrated photovoltaics, and is considered as a more efficient solution due to its ability to change its orientation unlike the common portable panels usually installed at the top of the buildings.

In 2012, two buildings in two different countries approached the concept of integrating shading elements with photovoltaics cells through two different applications, the first building is the Energy \& Environment Innovation Building in Japan (Fig.3a), the whole south \& west façades are covered by a solar envelope that is composed of almost 4570 kinetic photovoltaic panels, that open and close with different angles in response to the solar radiation amount in different seasons [12]. The other building is the RMIT Design Hub in Australia (Fig.3b), the building facade is composed of two layers at which the inner skin is composed of double glazed façade while the outer skin is an automated operable sun shading circular cells made of sandblasted glass and have been designed so that they can be replaced by photovoltaic cells [13].

Another example of the kinetic shading strategies with solar energy collection applications in buildings facades is the adaptive photovoltaic novel prototype cells at the Adaptive Solar Façade (House of Natural Resources), these cells combined together creates a self-supporting solar collection facade that can be applied on a wide 
range of existing buildings facades as an external layer so as to enhance its performance [14]. Externally installed solar panels on buildings facades can be linked together to a single mechanical driver which can help in continuously adjusting the pv panels orientation towards the sun. (Fig.3c). This can sometimes result in up to $40 \%$ savings and improve buildings efficiency in comparison to fixed static panels.

\subsection{Wind Driven Kinetic Responsive Facades}

Wind driven kinetic responsive facades are systems that respond to surrounding natural air current and wind, in order to provide high rates of natural ventilation to the inside of the buildings as well as to maintain high indoor air quality. Certain types of facades have also the ability to perform other functions such as controlling water vapour rates, odours and pollutants that usually accumulates inside poorly ventilated indoor spaces. Wind driven responsive systems goals can be achieved through either kinetic movement of façade elements in order to facilitate natural ventilation process \& provide appropriate thermal conditions in the inside of the buildings, or through generating electricity by converting wind energy into electrical energy, which is applicable in only some cases and types of buildings and its applications are usually less common.

\section{- Air Current Responsive Facades}

The first and most common type of kinetic air current responsive applications for environmental and sustainability purposes, is the type that responds to surrounding air current through the kinetic movement of building integrated facade elements, such as the case in the San Francisco Federal Building (Fig.4a), the natural ventilation main concept was to take advantage of the strong winds oriented towards the north-west façade during summer. Windows of all floors above the 5th floor are automatically controlled in response to wind speed and air current direction [15], to create what can be described as a living skin that facilitates natural ventilation throw allowing the intake of fresh air directly to the inside of the building through the day. While during night, all windows are automatically opened to flush out the accumulated heat and to allow the night cold air current to cool the inside of the building.

Just like San Francisco Federal Building, Manitoba Hydro Place (Fig.4b), was also designed from the beginning to depend on natural ventilation and to provide 100 $\%$ fresh air during the year through creating a highly energy efficient building. The envelope of the building is composed of an inner glazed facade and external double glazed façade with operable windows. [16] Windows located on the external facade are motorized so as to help in modulating the thermal conditions through natural ventilation, while windows located on the internal façade are manually operated for natural air intake according to occupant's preferences.

Another significant example is KfW Westarkade, Frankfurt, Germany (Fig.4c). the design concept was to provide the building with natural ventilation independent of the ambient conditions and external weather, so beside the buildings orientation, the outer skin is composed of a double-layered wind-pressurized façade consisting of windows which are closed in winter, at which the pressurized air inside the cavity wall acts like a thermal barrier and helps in providing the internal spaces with better thermal conditions. While in summer windows are opened, to allow the air flow through the façade and into the inside of the building. [17] 


\section{- Integrated Air Current Responsive Facades with Wind Turbines:}

The second and less common type of wind driven responsive strategies applications in buildings facades is wind energy harnessing through converting wind and air current energy into mechanical or electrical energy in order to decrease the reliance on non-renewable energy sources, as well as to decrease buildings energy consumption rates and increase buildings efficiency. Although a wide range of buildings have applied the idea of independently attaching wind catchers, turbines and cooling towers with different types and shapes externally to buildings, only few has actually integrated such concepts within the skin of the building façade itself through exploiting the concept of building mounted wind turbines. Some examples of these applications are clarified in this section.

One of the most interesting examples of this type of applications is the distinguished six yellow wind turbines installed at the top of $\mathrm{CH} 2$ Melbourne City Council House 2 (Fig.5a), that acts as a landmark in Melbourne city, Australia. The installed turbines which are integrated at the top of the building façade, doesn't only help in generating electricity from prevailing wind energy during the day, but also helps in extracting and exhausting the accumulated heat from the inside of the building during night [18]. Another example for wind energy collection façades is the Strata Tower in south London (Fig.5b), the tower front elevation is slightly concaved and oriented towards the south-west winds so as to channel and capture the maximum possible wind and air current, with three five special curved shape bladed (nine-meter diameter) wind turbines integrated at the top of the tower. The building was originally estimated to provide almost $8 \%$ of the total building's electrical energy needs [19].

While both of the above mentioned case studies has integrated wind turbines with different types to the top of their buildings facades, a totally different design solution was adopted in Greenway Self Park building (Fig.5c), at which the technology applied for harnessing wind energy in the building is based on installing lightweight aluminum vertical axis wind turbines that are installed vertically along the southwest corner of the building. One of the benefits of applying such system is that each one of the installed wind turbines has the ability to rotate independently and can also capture wind from different directions, which helps in increasing its efficiency and energy production rates. [20]

In the following part a number of 6 tables are represented, that clarifies and summarizes all the case studies discussed in the paper for both of the solar and wind driven kinetic responsive facades. 


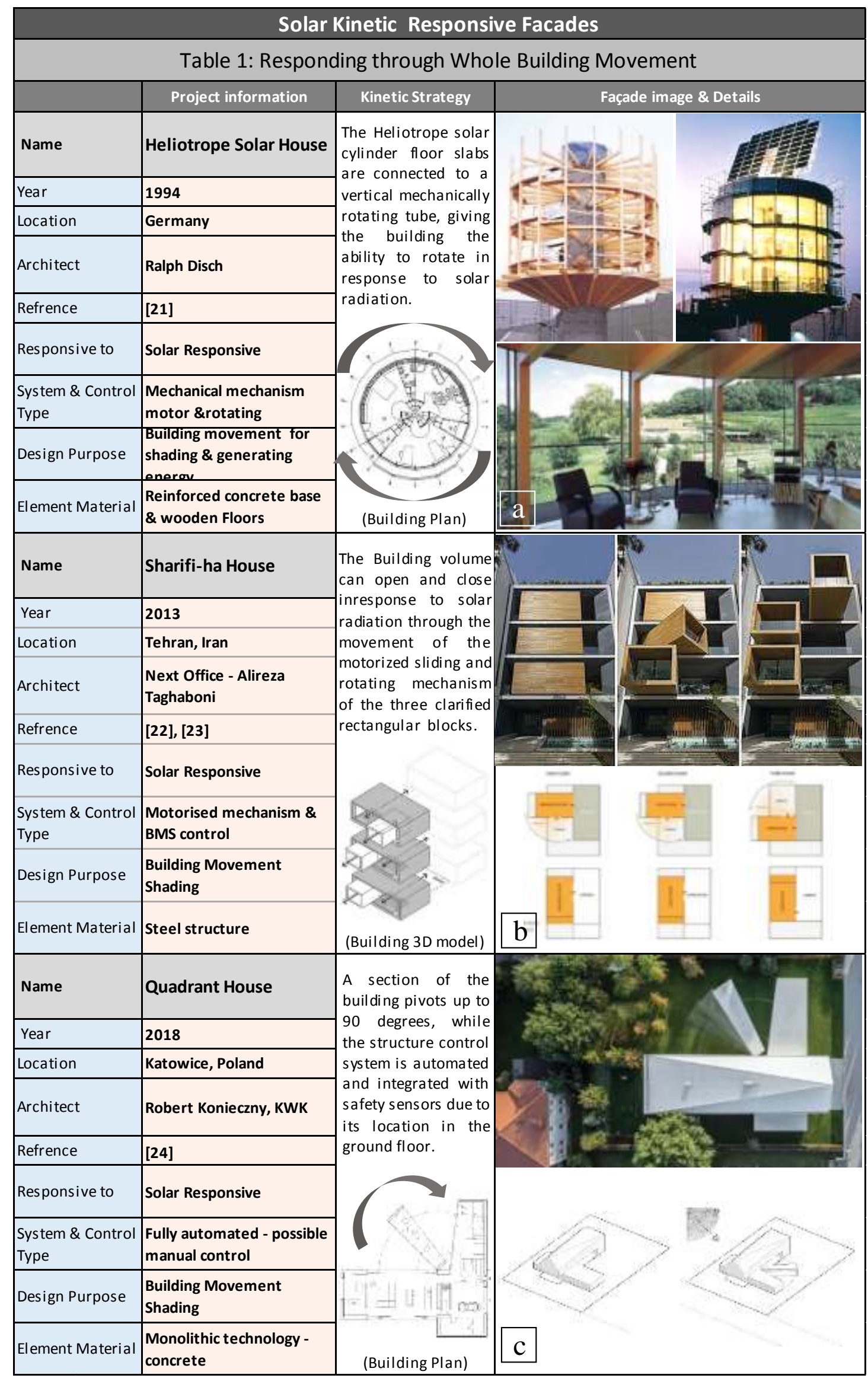




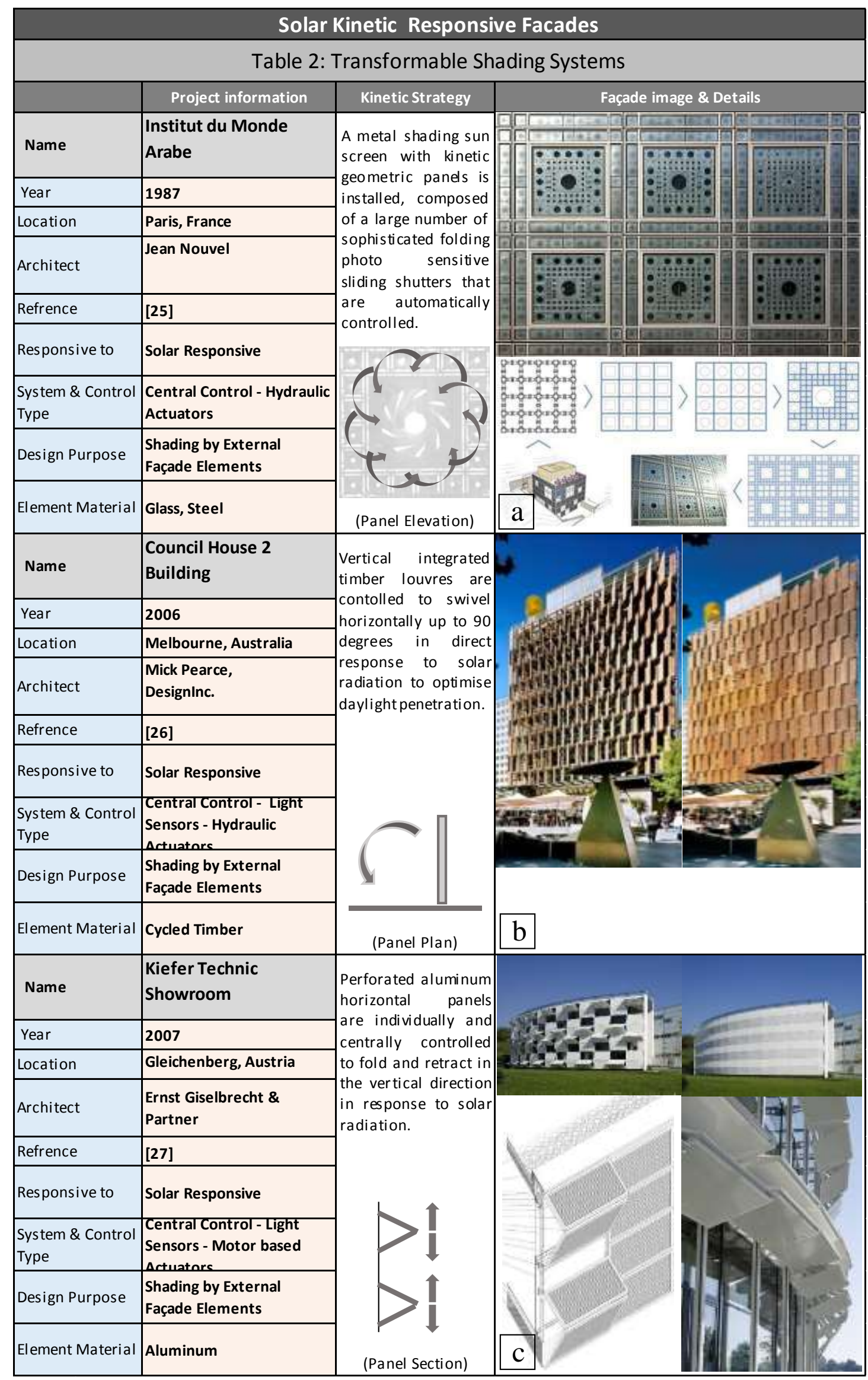




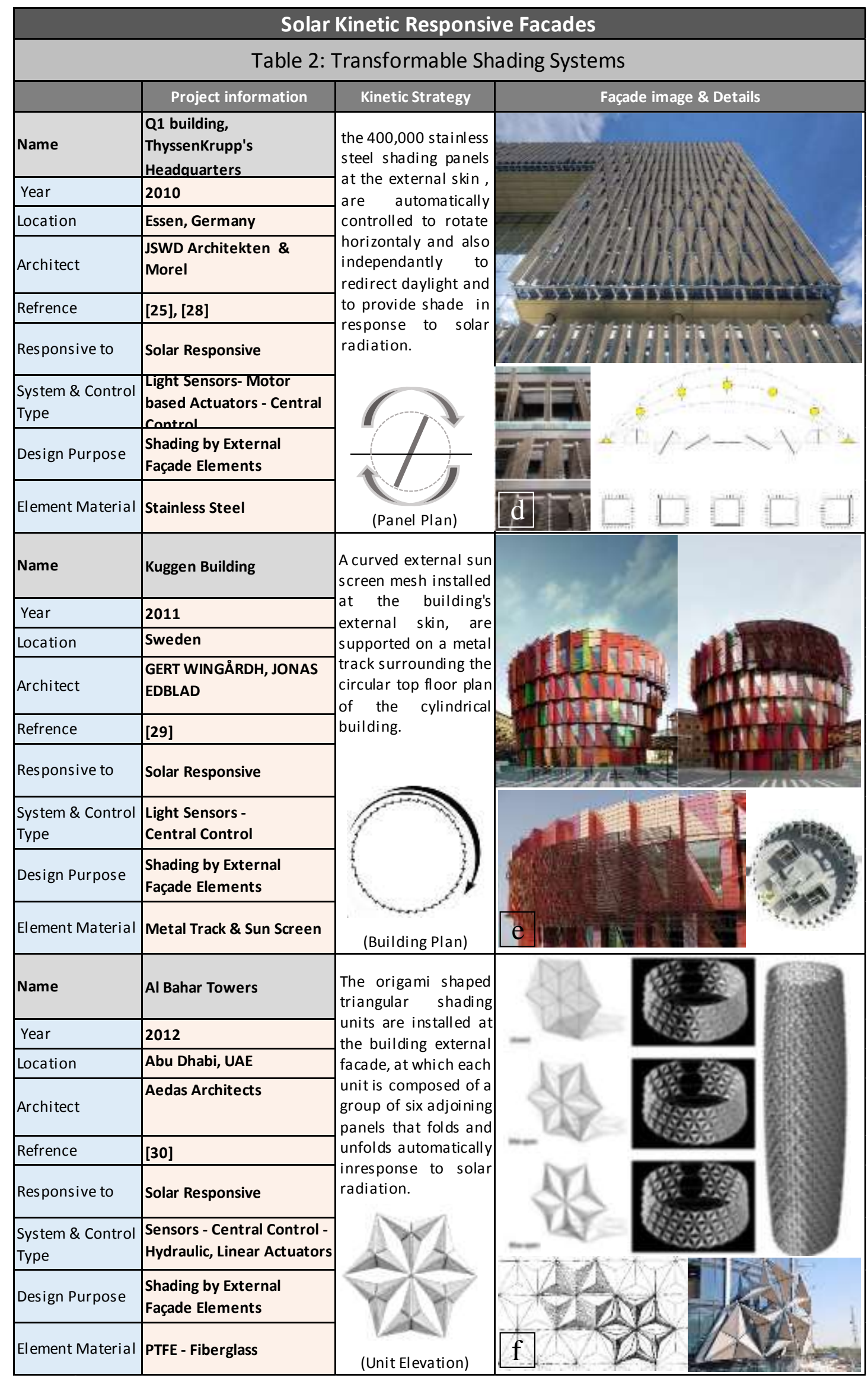




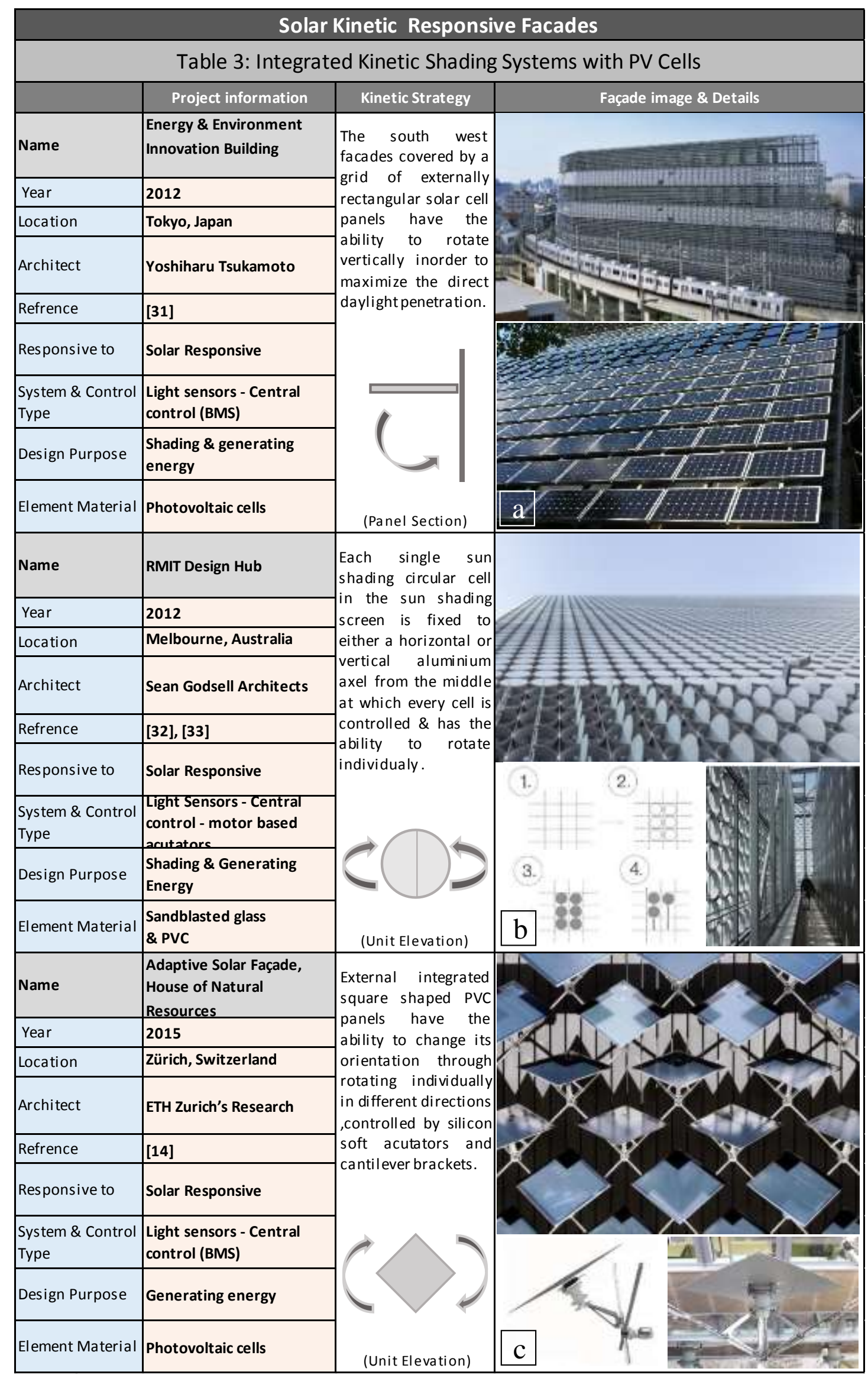




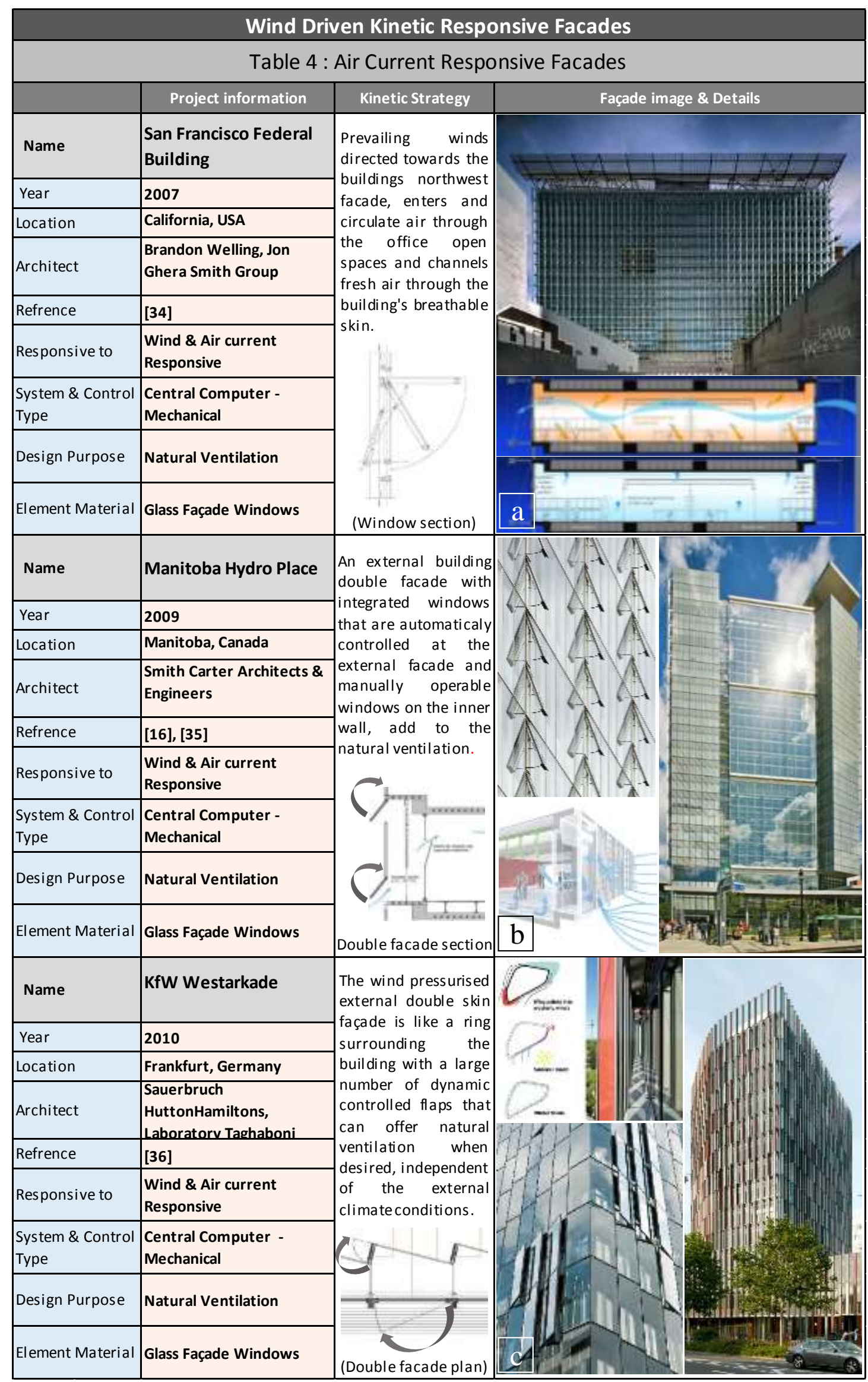




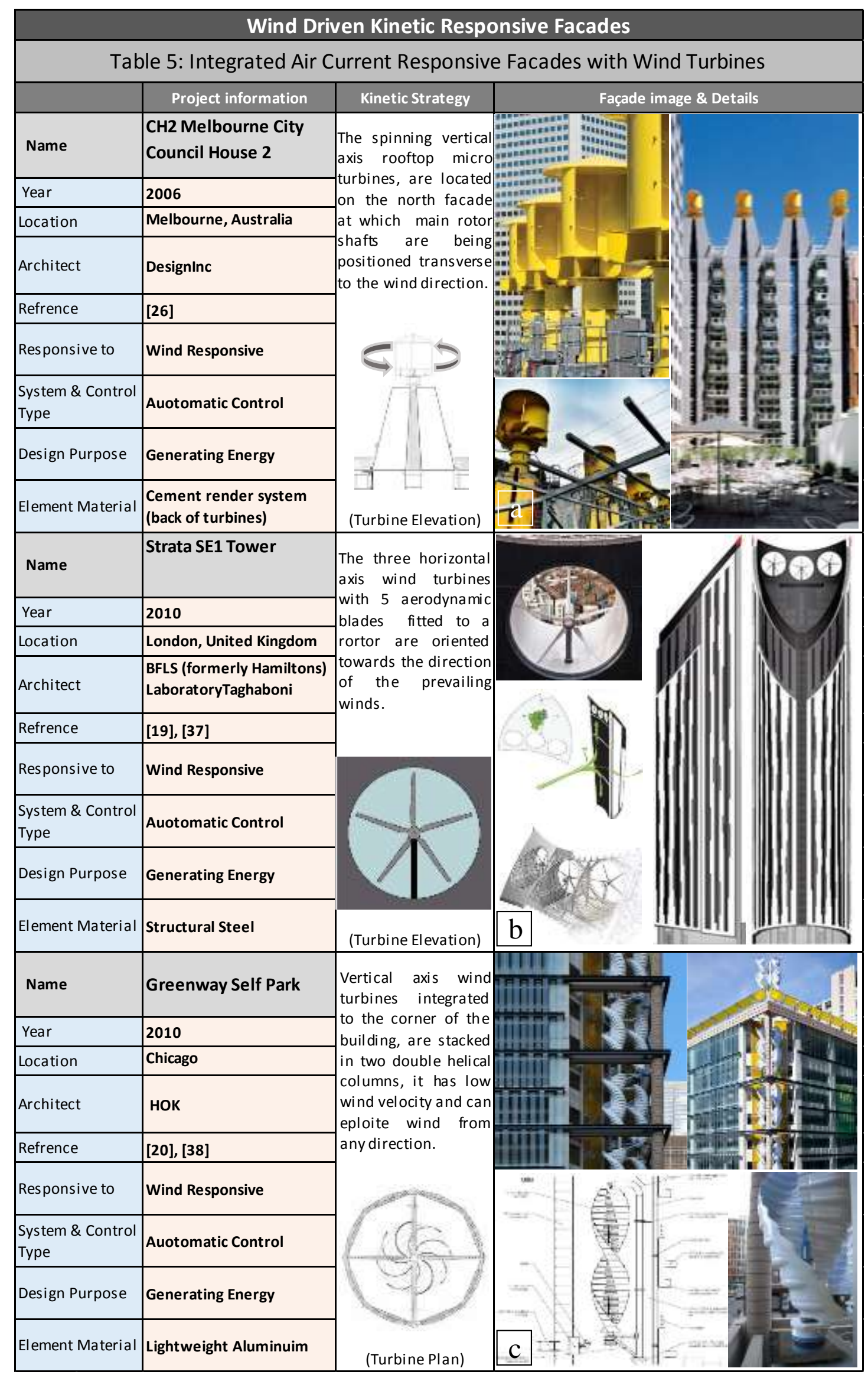




\section{Discussion:}

The first type of the illustrated case studies in the illustrated case studies, is the movement of the whole building or only particular buildings parts in response to solar radiation, such type of movement has been implemented in the early design stages of kinetic responsive design applications. Although this type of responsive behavior implements a dynamic structural system mechanism and needs a complex operating system, still it has proven to be successful in most of the existing case studies and efficiently responsive to the ambient environmental conditions, as well as adding an iconic \& aesthetic value to buildings in most of cases.

The second type of solar responsive facades is the applications of transformable shading systems which is the most common applied strategy in most of the responsive buildings facades applications. Many architects and designers have applied such strategy but with different technologies, materials and applications, many examples for such applications in buildings are available, but only some case studies have been mentioned in this research as examples for clarification of the wide range of complex shading systems and applications.

While the third and last clarified strategy of solar responsive strategies is considered to be an emerging design field with the intention of generating energy (from solar radiation) and has proved its efficiency through a number of recent applications in buildings facades mainly through integrating dynamic photovoltaic cells. In most of cases this types depends on the implementation of high cost complex operating \& control systems to create innovative solar building skins that have the ability to be installed on different existing external buildings facades.

On the other hand, it has been noticed that natural air current and wind driven responsive systems relatively new applications are also oriented to fulfill similar environmental goals but through responding within different range of behaviors according to the nature of affecting stimuli. There is a number of design considerations regarding wind effects and the study of temperature differences that have an influence on determining the appropriate type of implemented responsive behavior. Centrally controlled openings and windows can be integrated within responsive buildings external façade skin for regulating natural ventilation intake, also creating pressurized ventilated mediated space between the external double skin façades can help in providing comfortable indoor thermal conditions \& continuously regulating indoor ventilation rates.

Unlike solar responsive facades, generating electrical energy from wind energy through responsive facades integrated elements is not a commonly applied design concept. only few applications have actually tried to harness wind power or generate electricity through applying kinetic wind driven responsive concepts within buildings façades, as generating electrical energy from wind as a renewable source of energy usually requires the applications of wind turbines and its integration within external building's façade skin, that requires both high construction and maintenance costs, as well as the operation considerations that are needed to be taken into consideration as clarified in Table 6 below. 


\begin{tabular}{|c|c|c|c|c|c|}
\hline \multicolumn{6}{|c|}{ Table 6: Classification Summary } \\
\hline & & Project Name & Design Goals & Kinetic Response & Operation Considerations \\
\hline \multirow{12}{*}{ 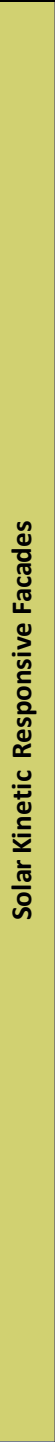 } & \multirow{3}{*}{ 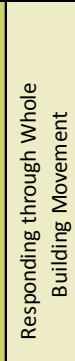 } & \begin{tabular}{|l} 
Heliotrope Solar \\
House
\end{tabular} & \begin{tabular}{|l|}
-Visual comfort \\
-Thermal comfort \\
•Energy Positive Solar \\
Home
\end{tabular} & $\begin{array}{l}-180 \text { degrees building } \\
\text { rotataion arround central } \\
\text { load-bearing column }\end{array}$ & \multirow{3}{*}{$\begin{array}{l}\text {-Dynamic buildings movement } \\
\text { requires innovative structural } \\
\text { solutions and mechanical } \\
\text { systems. } \\
\text {-Requires Complex and high } \\
\text { cost operating systems. }\end{array}$} \\
\hline & & Sharifi-ha House & •Thermal comfort & $\begin{array}{l}\text {-Openness \& closure of } \\
\text { building volume through } \\
\text { turning boxes }\end{array}$ & \\
\hline & & Quadrant House & -Thermal comfort & $\begin{array}{l}\text {-Segment of the house is } \\
\text { able to rotate } 90 \text { degrees }\end{array}$ & \\
\hline & \multirow{6}{*}{ 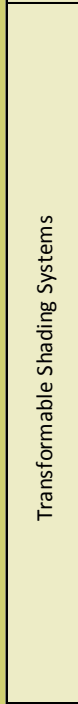 } & $\begin{array}{l}\text { Institut du } \\
\text { Monde Arabe }\end{array}$ & -Thermal comfort & $\begin{array}{l}\text {-Metal sun screen } \\
\text { composed of photo } \\
\text { sensitive sliding shutters }\end{array}$ & \multirow{6}{*}{$\begin{array}{l}\text {-Considerable attention for } \\
\text { material selection is required } \\
\text { to achieve performance and } \\
\text { operation efficiency. } \\
\text {-Different kinetic movement } \\
\text { typologies implemented in } \\
\text { each building is decided } \\
\text { according to design concept } \\
\text { and targeted building } \\
\text { performance. } \\
\text {-Operating shading strategies } \\
\text { may sometimes require the } \\
\text { integration between manual } \\
\text { and automated systems to } \\
\text { achieve occupant's } \\
\text { satisfaction. }\end{array}$} \\
\hline & & $\begin{array}{l}\text { Council House } 2 \\
\text { Building }\end{array}$ & \begin{tabular}{|l|}
-Visual comfort \\
-Thermal comfort
\end{tabular} & $\begin{array}{l}\text { Integrated vertical louvres } \\
\text { swivel horizontally to } 90 \\
\text { degrees }\end{array}$ & \\
\hline & & $\begin{array}{l}\text { Kiefer Technic } \\
\text { Showroom }\end{array}$ & \begin{tabular}{|l|}
-Visual comfort \\
-Thermal comfort
\end{tabular} & \begin{tabular}{|l|} 
Centraly controlled \\
horizontal folding \\
aluminum panels
\end{tabular} & \\
\hline & & \begin{tabular}{|l|} 
Q1 \\
ThyssenKrupp's \\
Headquarters \\
\end{tabular} & $\begin{array}{l}\text {-Visual comfort } \\
\text {-Thermal comfort }\end{array}$ & $\begin{array}{l}\text { •Horizontal rotation of } \\
\text { stainless steel shading } \\
\text { louvers \& panels }\end{array}$ & \\
\hline & & Kuggen Building & \begin{tabular}{|l|}
-Visual comfort \\
-Thermal comfort
\end{tabular} & $\begin{array}{l}\bullet \text { A curved rotating external } \\
\text { sun screen mesh }\end{array}$ & \\
\hline & & Al Bahar Towers & \begin{tabular}{|l|}
-Visual comfort \\
-Thermal comfort
\end{tabular} & $\begin{array}{l}\text {-Geometric panels slides to } \\
\text { create folding and } \\
\text { unfolding mechanism }\end{array}$ & \\
\hline & \multirow{3}{*}{ 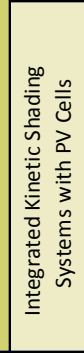 } & \begin{tabular}{|l|} 
Energy \& \\
Environment \\
Innovation Bldg \\
\end{tabular} & $\begin{array}{l}\text {-Visual comfort } \\
\text {-Thermal comfort } \\
\text {-Solar energy generation }\end{array}$ & $\begin{array}{l}\bullet \text { A grid of vertically rotating } \\
\text { rectangular solar cell panels }\end{array}$ & \multirow{3}{*}{$\begin{array}{l}\text {-Periodical surface cleaning is } \\
\text { required to maintain the } \\
\text { performance efficiency. } \\
\text {-Implementation of smart } \\
\text { control \& operating systems } \\
\text { are required. } \\
\text {-High cost of Initial PVC } \\
\text { installation. }\end{array}$} \\
\hline & & RMIT Design Hub & $\begin{array}{l}\text {-Visual comfort } \\
\text {-Thermal comfort } \\
\text {-Solar energy generation }\end{array}$ & $\begin{array}{l}\text { - Circular PV cells that } \\
\text { rotate around either } \\
\text { horizontal or vertical axis }\end{array}$ & \\
\hline & & \begin{tabular}{|l|} 
Adaptive Solar \\
Façade, House of \\
Natural Resources \\
\end{tabular} & $\begin{array}{l}\text {-Visual comfort } \\
\text {-Thermal comfort } \\
\text {-Solar energy generation }\end{array}$ & $\begin{array}{l}\text {-Dynamically rotating PVC } \\
\text { panels }\end{array}$ & \\
\hline \multirow{6}{*}{ 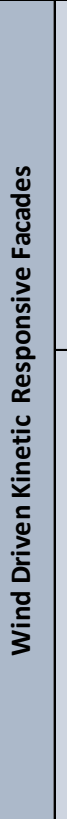 } & \multirow{3}{*}{ 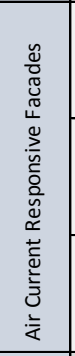 } & \begin{tabular}{|l} 
San Francisco \\
Federal Building
\end{tabular} & $\begin{array}{l}\text { •Natural ventilation } \\
\text {-Improved air quality }\end{array}$ & $\begin{array}{l}\bullet \text { A building's breathable } \\
\text { skin allows prevailed wind } \\
\& \text { fresh air to the indoors }\end{array}$ & \multirow{3}{*}{$\begin{array}{l}\text {-Temperature differences } \\
\text { between external \& internal } \\
\text { environments may require } \\
\text { different operation plans. } \\
\text {-The integration between } \\
\text { mechanical and natural } \\
\text { ventilation systems is required } \\
\text { to guarantee occupants } \\
\text { thermal comfort. }\end{array}$} \\
\hline & & $\begin{array}{l}\text { Manitoba Hydro } \\
\text { Place }\end{array}$ & $\begin{array}{l}\text {-Natural ventilation } \\
\text {-Improved air quality }\end{array}$ & $\begin{array}{l}\text {-Double facade with both } \\
\text { automated \& manually } \\
\text { operated windows }\end{array}$ & \\
\hline & & KfW Westarkade & $\begin{array}{l}\text {-Natural ventilation } \\
\text {-Improved air quality }\end{array}$ & \begin{tabular}{|l|} 
Wind pressurized \\
external double skin façade
\end{tabular} & \\
\hline & \multirow{3}{*}{ 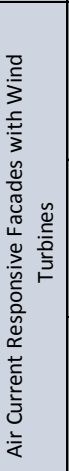 } & $\begin{array}{l}\text { CH2 Melbourne } \\
\text { City Council } \\
\text { House } 2\end{array}$ & -Wind energy generation & $\begin{array}{l}\bullet \text { A spinning vertical axis } \\
\text { rooftop integrated micro } \\
\text { turbines }\end{array}$ & \multirow{3}{*}{$\begin{array}{l}\text {-Surrounding urban context \& } \\
\text { buildings heights can lead to } \\
\text { air current turbulence which } \\
\text { affects the operation of wind } \\
\text { turbines. } \\
\text {-wind turbines Installation } \\
\text { may lead to vibration \& sound } \\
\text { pollution problems. } \\
\text {-Wind turbines integration } \\
\text { requires complicated } \\
\text { structural solutions. } \\
\text {-High cost maintenance }\end{array}$} \\
\hline & & Strata SE1 Tower & -Wind energy generation & $\begin{array}{l}\bullet A \text { three horizontal axis } \\
\text { wind turbines integrated at } \\
\text { the upper part of the } \\
\text { building }\end{array}$ & \\
\hline & & $\begin{array}{l}\text { Greenway Self } \\
\text { Park }\end{array}$ & -Wind energy generation & \begin{tabular}{|l|}
-Vertical axis wind turbine \\
integrated to building's \\
corner $\&$ stacked in 2 \\
double helical columns \\
\end{tabular} & \\
\hline
\end{tabular}


Based on reviews of representative case studies in this research, it was found out that different facades implemented wind turbines with different shapes, sizes and technologies. These applications are usually highly complicated and might be sometimes problematic, it needs to be installed at certain calculated heights in order to be certain that it will be able to catch sufficient air current and wind speed to work efficiently, also other considerations such as the vibration resulting from the movement of blades and turbines, sound pollution and structural loads needs to be taken into consideration. Unfortunately, it was claimed by a large number of researchers, designers and occupants, that some of the existing and clarified wind turbines applications within external buildings facades and rooftops in this research has some major downsides. Some of the recent claims have stated different reasons for the inefficiency of wind turbines applications in façade design, such as the three wind turbines installed at the top of the Strata Tower that was claimed by buildings residents that it rarely moved since the completion of its construction [39].

One of the expected reasons of wind turbines integration in building's façades inefficiency is the relatively low height of wind turbines applications as the friction caused by the ground and surrounding built environment produces turbulence which slow the flow of air current and accordingly affect the efficiency of energy generation [40], other mentioned reasons are usually referring to problems associated with sound proofing issues resulting from the vibration of buildings integrated wind turbines.

\section{Conclusion:}

The proposed classification in this paper is based on the analysis of a wide range of international case studies at which, it can be concluded that the majority of environmental kinetic responsive facades applications has two main significant goals, the first is to help in enhancing indoor environments through improving different comfort factors which can be described in terms of improving indoor air quality, thermal comfort levels, natural ventilation \& improving daylighting quality, which would lead eventually to decreasing buildings consumption rates and increase buildings efficiency. While the second goal goes far and beyond the desire to decrease buildings energy consumption rates, as this goal seeks to exploit the available natural energy sources such as solar radiation and wind, through implementing responsive elements in buildings facades that can respond in kinetic manner in order to help in generating electricity from ambient renewable sources rather than creating buildings that only depends on nonrenewable energy as its main source of power.

Many researches have been carried out about different climate responsive kinetic strategies. However, it was found from the discussion above that there is a current deficiency in the applications of energy generations through kinetic elements integration within building facades whether in solar responsive facades which has the potential of applying further innovative solar radiation collecting technologies, or in wind energy collection through applying wind turbines in buildings façades, that was shown to have many downsides which sometimes are major deficiencies that may even lead to its deactivation. this gives designers and researchers the chance to further investigate such significant field of study through further experimenting new innovative strategies and modified applications. 


\section{REFERENCES:}

[1] M Addington,Contingent behaviors, Architectural Design, 2009, pp. 12-17.

[2] Daniel Aeleneia,b, Laura Aeleneic, \& Catarina Pacheco Vieirab, Adaptive Façade: concept, applications, Research Questions, 2016.

[3] Rolf-disch, the-heliotrope-house, Cited: https://www.yumpu.com/en/document/read/23000263/the-heliotrope-as-hotelpdf-8-pages-english-rolf-disch, (Accessed on 2/11/2020).

[4] Agnes Nyilas, Yoshihito Kurazumi, On the Aesthetics of Seasonally Adaptive Buildings - A Morphological Approach towards Climate Responsive Architecture, Department of Human Environmental Design, Sugiyama Jogakuen University, Nagoya, Japan, 2017.

[5] Quadrant House, 2018, Cited: https://www.architonic.com/en/project/robertkonieczny-kwk-promes-quadrant-house/20041795, (Accessed on 10/11/2020).

[6] B. Kolaveric, V. Parlac, Adaptive, Responsive Building Skins, in Building Dynamics: Exploring Architecture of Change, Routledge Taylor \& Francis Group, London and New York, 2015, Chapter 12, pp. 69-88.

[7] Dominique Hes, Centre for Design, Royal Melbourne Institute of Technology, Mark Cummings Advanced Environmental Concepts, $\mathrm{CH} 2$, Melbourne City Council, Australia, London, 2005, p.9.

[8] Mina. Omrani, Abdollah. Jabal Ameli, Dynamic Facades in Buildings In Case Of Decreasing Energy Usage, 6th International Conference on Civil, Architectural \& Environmental Sciences, June 19, 2019.

[10] International Congress on Construction Management Research, Management of Construction, Research to Practice, Birmingham City University, Montreal, Canada, 26 - 29 June 2012, Volume2.

[11] A Shady Attia, Evaluation of adaptive facades: The case study of Al Bahr Towers in the UAE, Research article, QScience Connect, 2017.

[12] Energy and Environment Innovation Building, Australian design review, Cited: https://www.australiandesignreview.com/architecture/energy-and-environmentinnovation-building/, (Accessed on 20/10/2020).

[13] Xueqi Fan, Kinetic Architecture: Reimagining the Facade of the UW Tower, University of Washington, 2020.

[14] ASF - Adaptive Solar Façade, Moritz Begle, Cited: http://www.moritzbegle.com/asf---adaptive-solar-facade.html, (Accessed on 1/12/2020).

[15] Richard de Dear, Thermal comfort in natural ventilation a neurophysiological hypothesis, University of Sydney, Australia, 2009.

[16] B. Kuwabara, T. Auer , T. Akerstream , M. Pauls, Manitoba Hydro Place: Design, construction, operation, PLEA2013 - 29th Conference, Sustainable Architecture for a Renewable Future, Munich, Germany 10-12 September 2013.

[17] Kolarevic, B. Parlac, V. 2015. Building Dynamics: Exploring Architecture of Change. Chapter 6: Adaptive, Responsive Building Skins. Routledge, p:69-89.

[18] Dominique Hes, RAHMAT BAYUDI, Council House 2 (CH2), Melbourne CBD, A Green Building Showcase in the Making., Conference on Sustainable Building South East Asia, Malaysia, 13 April 2005.

[19] Ian Bogle, Integrating Wind Turbines in Tall Buildings, CTBUH Research Paper, 2011, Issue IV.

[20] Dalia Abd El Rahman1, Gihan Mosaad1, Fahd AbdElAziz Hemeida, \& Ahmed Ramadan, Modelling Zero Energy Building: Parametric Study for the Technical Optimization, Journal of Al-Azhar University, Vol.15, No. 56, July 2020. 
[21] Heliotrope: Solar Home, inhabitat, Cited: https://inhabitat.com/heliotrope-theworlds-first-energy-positive-solar-home/, (Accessed on 15/12/2020).

[22] Jaafar A. Ibrahim, Halil Z. Alibaba, Kinetic Facade as a tool for Energy Effceincy, International Journal of Engineering Research \& Reviews, Dec.2019.

[23] Ahmet V. Orhon, Adaptive Building Shells, October 2016.

[24] Quadrant House, KWK Promes R. Konieczny, the plan, Cited: https://www.theplan.it/eng/award-2019-house/quadrant-house, (Accessed on 11/12/2020).

[25] Yasmin M. El Semary, Hany Attalla \& Iman Gawad , Modern Mashrabiyas with High-tech Daylight Responsive Systems, The International Conference : Cities' Identity Through Architecture and Arts (CITAA).

[26] Melbourne city council house 2, Cited: https://www.archdaily.com/395131/ch2-melbourne-city-council-house-2 designinc/51cc716db3fc4b2142000075-ch2-melbourne-city-council-house-2designinc-photo?next_project=no, (Accessed on 23/12/2020).

[27] B. Gleichenberg, Austria, Ernst Giselbrecht \& Partner, Architonic, Cited: https://www.architonic.com/en/project/ernst-giselbrecht-partner-dynamic-facadekiefer-technic-showroom/5100449, (Accessed on 23/12/2020).

[28] Fahad Alotaibi, The Role of Kinetic Envelopes to Improve Energy Performance in Buildings, Architectural Engineering Technology, 2015.

[29] Kuggen, Cited: https://en.wikiarquitectura.com/building/kuggen/\#, (Accessed on 2/9/2020).

[30] El-Semary. Y. March 2014. Kinetic Architecture as a tool for Sustainability, M.Sc. in Architecture, Cairo, Egypt: Faculty of Fine Arts, Helwan university.

[31] Energy \& Environment Building, Cited: https://www.australiandesignreview.com/architecture/energy-and-environmentinnovation-building/, (Accessed on 29/12/2020).

[32] Parametric Façade Decoding, Iaac Barcelona, Educational programs, Cited: http://www.iaacblog.com/programs/parametric-facade-decoding-2/, (Accessed on 13/12/2020).

[33] Xueqi Fan, Kinetic Architecture: Reimagining the Facade of the UW Tower, University of Washington, 2020.

[34] United States Federal Building, Cited: https://arcspace.com/feature/united-statesfederal-building/, (Accessed on 2/1/2020).

[35] KPMB, Manitoba Hydro Place, Cited: https://divisare.com/projects/386636quinn-manitoba-hydro-place, (Accessed on 14/1/2020).

[36] KfW Westarkade, Frankfurt, Germany, Cited: https://transsolar.com/projects/kfw-westarkade, (Accessed on 20/1/2020).

[37] The Sustainability of Strata Se1 from a Technical Perspective, Cited: https://msayear2stratatower.wordpress.com/2013/01/11/the-sustainability-ofstrata-se1-from-a-technical-point-of-view/, (Accessed on 21/12/2020).

[38] Greenway Self Park, Cited: http://spacedbm.com/bbs/board.php?bo_table=portfolio\&wr_id=73\&ckattempt=1, (Accessed on 3/2/2020).

[39] The rarely spinning turbines of the Strata Tower, south London, Cited: http://www.urban75.org/blog/the-rarely-spinning-turbines-of-the-strata-towersouth-london/, (Accessed on 6/2/2020).

[40] Blake Herrschaft, Stop putting wind turbines on buildings, Energy in Transition, 18 Aug. 2016, Cited: https://blogs.dnvgl.com/energy/stop-putting-wind-turbineson-buildings, (Accessed on 6/2/2020). 